УДК 631.356.22

DOI 10.36910/6775-2313-5352-2020-17-12

Ліннік А.Ю., Семенів І.І., Кирик О.М.

Відокремлений підрозділ Національного університету біоресурсів і природокористування України «Бережанський агротехнічний інститут»

\title{
ГИЧКООЧИСНИЙ ПРИСТРІЙ. КОНСТРУКЦІЯ ТА КІНЕМАТИКА РУХУ
}

Природний потенціал сільськогосподарських угідь України дозволяє стати лідером по виробництві иукру в Європі. Проте, для успішного виходу на європейські ринки необхідно забезпечити конкурентоспроможність виготовленої продукиії, щзо можна досягти різними шляхами, зокрема: підвищення якості сировини, зниження затрат праці та енергоємності процесів виробнищтва.

Проведено аналіз класичних технологій очищення голівок коренеплодів та їх збирання, вплив різних конструктивних схем очищувальних пристроїв на чистоту голівки та иілісність тіла кореня з урахуванням енерговитрат на процес. Досліджено проблему удосконалення існуючих та винайдення нових конструкиій гичкоочисних машин з урахуванням фізикомеханічних властивостей тіл контакту очисник-коренеплід, якість роботи яких задовільнила б агротехнічні вимоги.

У статті запропоновано нову конструкиію пристрою для зрізування гички та очищення головок коренеплодів иукрових буряків в якій поєднано два технологічних прочеси - зрізування гички та послідуюче доочищення поверхні голівки коренеплоду жорсткою поверхнею диска та еластичними бичами за умови копіюванні висоти росту кожного коренеплоду.

Результатом дослідження є визначенні перспективи вдосконалення технології очищення гички иукрових буряків,запропоновано нову конструкцію очисної машини комбінованої дії.

Ключові слова: гичка, залишки гички, коренеплід, иукровий буряк, очистка, доочищення.

Постановка проблеми. Природний потенціал сільськогосподарських угідь України дозволяє стати лідером по виробництві цукру в Європі. Проте, для успішного виходу на європейські ринки необхідно забезпечити конкурентоспроможність виготовленої продукції, що можна досягти різними шляхами, зокрема: підвищення якості сировини, зниження затрат праці та енергоємності процесів виробництва.

Виробництво цукрової сировини на теренах нашої держави зосереджене на вирощуванні цукрового буряка. Протягом останніх років за даними Держкомстату України [1] на вітчизняних полях спостерігається тенденція збільшення площ посівів цукрового буряка. Це зумовлено тим, що основний продукт - цукор є базовою сировиною для багатьох харчових виробництв, а тому є важливою складовою продовольчої безпеки держави. На виробництво цукру визначальний вплив має якість підготовки сировини, тобто коренеплодів цукрових буряків, а саме їх цукристість, ступінь пошкодження та якість очистки від грунту та залишків гички.

Збирання врожаю цукрового буряка проводиться в основному комбайнами, якої за один робочий хід виконують цілий ряд операцій - безкопірне зрізання гички за часто пасивними зрізуючими робочими органами, викопування коренеплоду, очищення кореня від залишків грунту [2,3]. Проте, в даних машинах не приділено достатньо уваги питанню відділення залишків гички від тіла коренеплоду. Забруднення викопаних коренеплодів залишками гички негативно впливає на процес цукроваріння, що в свою чергу веде до збільшення витрат на сам процес, а відповідно збільшується собівартість кінцевого продукту. Поряд з тим, існує ще ряд ускладнень пов'язаних із забрудненням залишками гички, а саме, збільшення енерговитрат на транспортування сировини до місць кагатування і до площадок заводів та втрати при зберіганні в кагатах через гниття коренів, яке сильно залежить від наявності залишків гички, оскільки в ній зберігається надлишкова волога яка активно сприяє розвитку мікроорганізмів та грибків збудників гнилей.

Постає проблема удосконалення існуючих та винайдення нових перспективних конструкцій очисних та доочисних робочих органів збиральних машин, обгрунтування раціональних режимів їх роботи та, в кінцевому результаті, забезпечення даної галузі якісною та надійною технікою. 
Аналіз останніх досліджень та публікацій. Відомо, що для зменшення енергозатрат та часу збирання врожаю цукрових буряків проводиться прямим комбайнуванням при виконанні операцій очистки гички на корені та викопування коренеплодів однією машиною [2]. Проте, дослідження показали незадовільну якість очистки залишків гички на викопаних коренеплодах, причиною чого $є$ недосконалість конструкції та режимів роботи очисних пристроїв $[4,5]$.

Фундаментальні основи дослідження процесу доочищення коренеплодів від залишків гички викладені у працях проф. Вовк П.Ф., який в 1936 році опублікував статтю в якій викладені фізико-механічні агробіологічні властивості цукрових буряків, залежності між окремими розмірами буряків та втрати цукристої маси коренеплодів при різних способах зрізування коронки. Ця робота, а також праці українських вчених Василенка А.О., Бурмістрової М.Ф., Тат'янка М.В., Денисенка I.I., Погорілого Л.В., Зуєва М.М. справили основоположний вплив на розвиток бурякозбиральних машин. Значну увагу вивченню біологічних та фізикомеханічних властивостей цукрових буряків у зв'язку з механізацією їх збирання приділяли також за кордоном.

Математичним моделюванням процесу доочищення голівок коренеплодів на доочисними агрегатами, а також теоретичними дослідженням цього процесу займалися такі видатні вчені як Погорілий Л.В., Булгаков В.М., Мартиненко В.Я..

Незважаючи на досить широке дослідження питання доочищення голівок коренеплодів від залишків гички, деякі способи завдяки яким можна досягнути необхідної чистоти вороху коренеплодів пов'язані зі значними пошкодженями самого тіла коренеплоду при використанні жорстких i пружних доочисних органів, a також зустрічаються робочі органи які характеризуються складною конструкцією, яка невзмозі забезпечити довготривалу роботоздатність процесу.

Тому виникає необхідність створення конструктивно нового робочого органу виходячи 3 таких умов як, мінімальне пошкодження тіла самого коренеплоду, невибиванння його з рядка, задовільного ступеня доочистки голівки коренеплоду що можна досягнути вирішивши конструктивні задачі та обгрунтувати раціональний режим роботи конкретного очисника враховуючи фізико-механічні властивості контактуючих тіл.

Мета, завдання та методика досліджень. Метою дослідження виступає підвищення якості очищення коренеплодів від гички та зниження енергомісткості процесу очистки шляхом створення нової конструкції робочого органу, який би забезпечував якісні показники виконання операції відповідно до агротехнічних вимог при мінімальних енергозатратах та обгрунтування кінематичного режиму роботи очисника.

Для досягнення поставленої мети необхідно виконати наступні завдання: провести дослідження відомих конструкцій очисників коренеплодів з метою виявлення причин зниження якості очищення коренеплодів, розробити нову конструктивну схему очисника з урахуванням недоліків відомих конструкцій, обгрунтувати кінематичний режим роботи машини 3 урахуванням фізичних та механічних властивостей контактуючих тіл та за умови відсутності пропусків контакту лопать-поверхня голівки коренеплоду.

Об’єкт дослідження - процес взаємодії доочисника 3 головками коренеплодів та залишками гички

Проведення досліджень здійснювались 3 використанням загальних методик дослідження (спостереження, порівняння, аналіз, патентний пошук)та методів теоретичної та аналітичної механіки істатистики

Результати досліджень. Однією 3 основних агротехнічних вимог, що ставляться до гичковидаляючих машин $є$ якість очищення голівок коренеплодів від залишків гички, які не повинні перевищувати 3 \% по масі. Відомі конструкції обрізуючих пристроїв, а також пасивних дообрізувачів гичкозбиральних машин, які проводять для забезпечення необхідної чистоти сировини зріз частини голівки коренеплоду разом із гичкою на рівні основи черешків застосовувати не раціонально, оскільки мають місце втрати цукристої маси $6 \ldots 8 \%[4,5]$.

Поставлена мета досягається тим, що новостворена конструкція очисника голівок коренеплодів від залишків гички (рис.1) виконує одночасно дві технологічні операції копірний по висоті зріз гички коренеплоду та послідуюче доочищення поверхні голівки еластичним та жорстким робочими органами [6]. Копіювання висоти росту голівок коренеплоду $є$ основою для запобігання зрізу частини тіла кореня, також цьому сприяє шарнірне кріплення обрізуючих ножів на поверхні копіюючого диска, які при находжені на коренеплід відхиляються і зрізають частини голівки. 


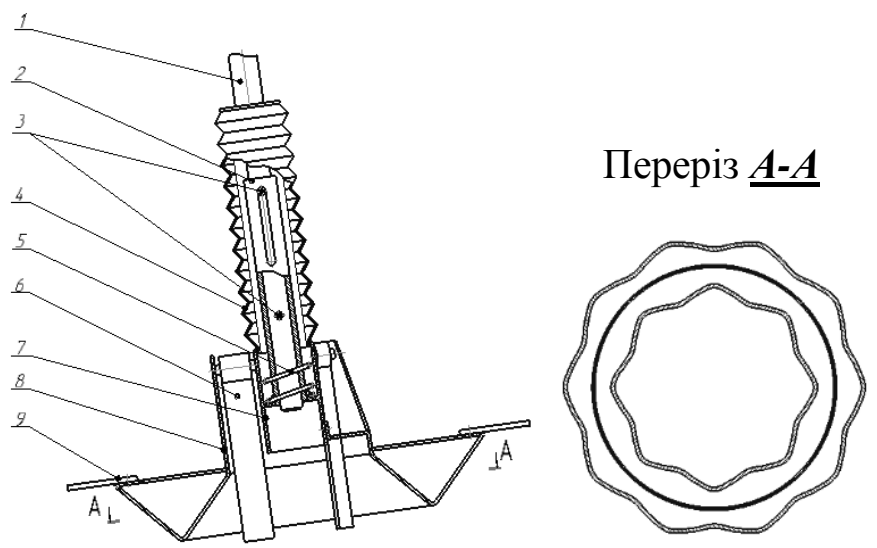

Рис.1. Пристрій для одночасного зрізування гички та очищення головок коренеплодів цукрових буряків [6]: 1 - вал, 2 - втулка, 3 - штифт, 4 - кожух, 5 - пружина, 6 - еластична лопать, 7 - маточина, 8 - диск, 9 - ніж.

Така альтернатива обрізюючим ножам, які часто використовуються в коренезбиральних машинах і проводять зріз голівки коренеплоду на рівні основи черешків, виникає з метою збереження цілісності голівки коренеплоду і відповідно знизити втрати врожаю коренів на $6 \ldots 8 \%$. Для досягнення необхідної чистоти поверхні голівки коренеплоду застосовується доочищення жорсткою ребристою поверхнею копіюючого конусного диска, який проводить обламування черешків, або їх приминання, та послідуюче доочищення еластичними лопатями, які повністю обгортають надземну поверхню кореня і зчісують залишки гички. Зусилля з яким діє на поверхню голівки ребриста поверхня копіюючого диска регулюється стисканням пружини копіювального пристрою, а зусилля еластичних робочих органів - швидкістю обертання робочого вала пристрою.

Запропонована конструкція пристрою для одночасного зрізування гички таочищення головок коренеплодів цукрових буряків виконана у вигляді рами, яка обладнана начіпним механізмом та опорно-копіюючими колесами (на рис не показано), на якій встановлений вал 1 під кутом до вертикалі, зв'язаного з втулкою 2 за допомогою двох штифтів 3, встановлених у валу таким чином, що їхні кінці знаходяться в пазах втулки і забезпечують можливість осьового переміщення втулки відносно вала, при чому, рухома пара втулка-вал закрита пилозахисним гофрованим кожухом 4. Втулка, за допомогою маточини 7, жорстко з'єднана 3 диском 8 , який складається з несучої частини, на якій встановлено через $90^{\circ}$ обрізуючі ножі 9 та очисні еластичні лопаті 6, закріплені через $120^{\circ}$ та копіюючої, виконаної у вигляді конуса, направленого меншою частиною вниз, причому, поверхні конуса є ребристими.

Пристрій для зрізування гички та очищення головок коренеплодів цукрових буряків містить встановлений під кутом до вертикалі вал 1, на якому встановлена втулка 2, в пазах якої розташовані вільними кінцями штифти 3 , що забезпечують можливість осьового переміщення втулки відносно вала. Під дією пружини 5 втулка підтиснута в крайнє нижнє положення, при цьому рухома пара втулка-вал закрита пилозахисним гофрованим кожухом 4. Втулка, за допомогою маточини 7 жорстко 3'єднана 3 диском 8, копіювальна частина якого виконана у вигляді конуса і направлена меншою основою вниз, причому поверхні конуса $є$ ребристими. На несучій частині диска, шарнірно встановлені через $90^{\circ}$ обрізуючі ножі 9, та на осях, закріплених одним кінцем в диску, а іншим у втулці, еластичні очисні елементи - лопаті 6 через кожні $120^{\circ}$.

Пристрій для зрізування гички та очищення головок коренеплодів цукрових буряків працює наступним чином. При русі агрегату вздовж рядка приводиться в рух вал 1 і відповідно диск 8 , котрий приводить в рух ножі 9 та очисні елементи 6. Гичка зрізується ножами i відкидається з оброблювальної зони. Очищення від залишків гички проходить в два етапи: спершу при копіюванні висоти росту коренеплоду в контакт з голівкою вступають ребристі конусні поверхні диска обламуючи та зчісуючи черешки гички за рахунок своєї профільної поверхні, далі очисні елементи 6 проводять додаткове обчісування залишків гички на голівці коренеплоду. Таким чином, відбувається одночасне зрізування гички 3 винесенням іiі за межі рядка та очищення головок коренеплодів.

Копіювання висоти росту коренеплодів виконується копіювальною частиною диска 8 наступним чином. При зустрічі з високим коренеплодом конус ковзає по голівці коренеплоду і 
піднімає диск на необхідну висоту. Після проходження голівки коренеплоду під дією пружини 5 диск опускається, при цьому очищений коренеплід не впливатиме на копіювання висоти росту наступного коренеплоду, оскільки проходитиме під поверхнею копіювальної частини диска завдяки куту нахилу осі валу до вертикалі.Розміщення копіювального елемента безпосередньо на очисному диску забезпечує підвищення якості очистки голівок коренеплодів та спрощує в цілому конструкцію очисника.

Кінематичний режим роботи очисника визначається за умови відсутності пропусків контакту лопать-поверхня голівки коренеплоду що забезпечить мінімальне пошкодження коренів за рахунок повторного контакту лопатей з коренем.

В даному випадку, вісь обертання очисника розташована під кутом до поверхні грунту, але для спрощення розрахунку вважатимемо що вісь розміщення перпендикулярно до поверхні грунту відповідно і напрямку руху очисника $v_{m}$ (рис.2). При обертанні вала очисника з кутовою швидкістю $\boldsymbol{w}$, кінці лопаті матимуть колові швидкості у відносному русі $[7,8]$ :

$$
v=w l
$$

де $\quad \boldsymbol{l}$ - відповідно довжина лопаті.

В абсолютному русі лопаті робочого органу здійснюють рух по гвинтовій лінії (рис.3).

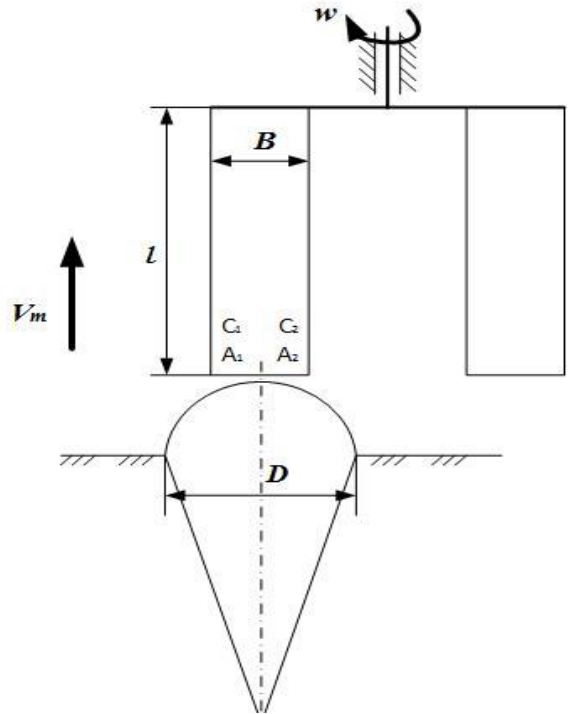

Рис.2. Загальна схема взаємодії лопаті очисника з головкою коренеплоду

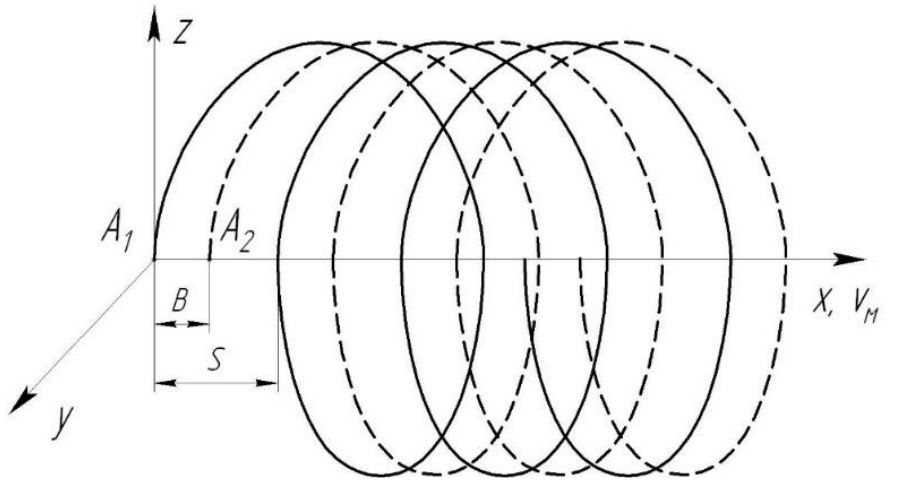

Рис. 3. Траєкторія абсолютного руху кінцевих точок лопаті очисника коренеплодів

Параметром цієї гвинтової лінії є величина $S$ (відстань між сусідніми однойменними точками однієї лопаті) за повний оберт робочого органу при проходженні шляху $t_{s} v_{m}$. При цьому час $t_{w}$, за який відбувається повний оберт очисника, дорівнює (за умов наявності однієї лопаті):

$$
t_{w}=\frac{2 \pi}{w} .
$$

А час, за який машина пройде шлях $S$, становить:

$$
t_{s}=\frac{S}{v_{m}} .
$$

Для запобігання пропусків контакту лопаті 3 головкою кореня необхідно щоб виконувалась умова: $\quad t_{\mathrm{w}}$, або $\frac{2 \pi}{w} .3$ урахуванням наявності декількох $(n)$ лопатей, останній вираз матиме вигляд:

$$
\frac{2 \pi}{n w} \leq \frac{S}{v_{m}}
$$

А якщо враховувати ширину лопаті $B$, тобто $S=B$, то останній вираз матиме вигляд: $\frac{2 \pi}{n w} \leq \frac{B}{v_{m}}$. Помноживши праву та ліву частини цього виразу на $v_{m}$ та виконавши деякі 
перетворення, можна отримати величину відношення переносної та кутової швидкостей очисника, яка забезпечує відсутність пропусків контакту лопатей очисника 3 головкою коренеплоду:

$$
\frac{v_{m}}{w} \leq \frac{B n}{2 \pi}
$$

Таким чином вираз (5) є кс

с ччччччччоефіціснтом кінематичного режиму роботи ротаційного очисника $з$ віссю обертання перпендикулярної до напрямку переносної поступальної швидкості (швидкості машини).

Кінематичний аналіз механізму навіски доочисника 3 метою визначення швидкостей та прискорень які отримує механізм навіски при копіюванні мікрорельєфу поля проведено у відповідності 3 [8]. Для розрахунку вважатимемо що нерівності мікрорельєфу поля співпадають по величині i фазі 3 синусоїдальною кривою, у якої довжина хвилі i амплітуда коливання рівні середньому кроку і середній амплітуді нерівностей поверхні реального поля. Таке

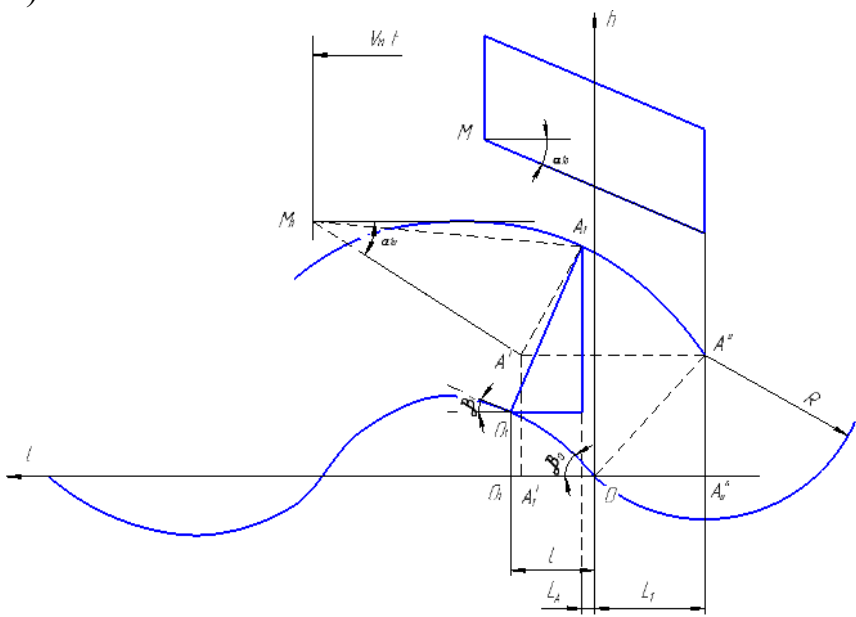

Рис. 3. Схема руху механізму навіски 3 опорно-копіювальними колесами. кінематичний аналіз механізму навіски без урахування впливу випадкових факторів.

При русі регулювально-опорних полозів по синусоїдальному профілю(рис 3) точка А, центр радіуса кривизни загину кінця полоза, буде рухатись по кривій, точки якої будуть рівновіддалені від синусоїди.

Прийнято, що координати початкового положення точки А будуть рівні $\mathrm{H}_{0}$ i $\mathrm{L}_{0}$.

$L_{0}=-O A^{\circ} \sin \beta_{0}=-R \sin \beta_{0}$

$$
H_{0}=O A^{\circ} \cos \beta_{0}=R \cos \beta_{0}
$$

Через проміжок часу рівний $t_{1}-t_{0}=t$, точка А займе положення $\mathrm{A}_{1}$, тоді:

$$
\begin{array}{r}
H_{1}=R \cos \beta_{1}+h_{1}=R \cos \beta_{1}+\lambda \sin \frac{2 \pi}{L} l \\
L_{1}=O_{0} O-O_{0} B_{0}=l_{1}-O_{1} A_{1} \sin \beta_{1}=l_{1}-R \sin \beta_{1}
\end{array}
$$

Поточні координати точки А визначено за формулою:

$$
L_{A}=l-R \frac{H_{A}=\lambda \sin \frac{2 \pi}{L} l+R \frac{1}{\sqrt{1+\lambda^{2} \frac{4 \pi^{2}}{L^{2}} \cos ^{2} \frac{2 \pi}{L} l} \cos \frac{2 \pi}{L} l}}{\sqrt{1+\lambda^{2} \frac{4 \pi^{2}}{L^{2}} \cos ^{2} \frac{2 \pi}{L} l}}
$$

У випадку, якщо точка А рухалась по прямій, паралельно осі координат, та за час $\mathrm{t}$ вона зміститься в положення А' і пройде шлях $\overline{\mathrm{A}^{\circ} A^{s}}=\overline{v_{M} t}$.

3 іншого боку:

$$
v_{M} t=L_{A}-L_{0}+\left(H_{A}-H_{0}\right) \tan \left(\alpha-\frac{\arcsin \frac{M_{\rho}}{2}}{2}\right)
$$

Підставивши сюди значення $L_{A}, L_{0}, H_{\mathbb{A}}$ i $H_{0}$ і визначивши його відносно t, отримаємо:

$$
t=\frac{l+\tan \left(\alpha-\frac{\arcsin \frac{m}{\rho}}{2}\right) \lambda \sin \frac{2 \pi}{L} l}{v_{M}}+
$$




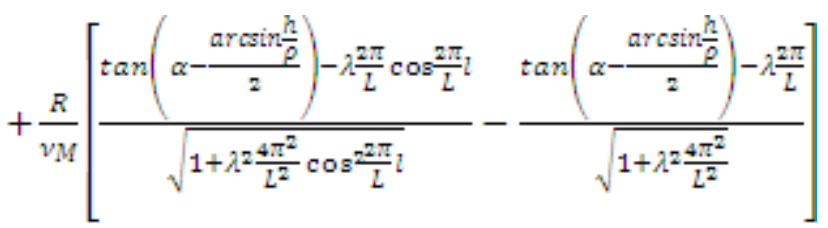

Таким чином, формули (6) та (10) є рівнянням шляху вертикального переміщення точок механізму з опорно-копіювальними колесами в залежності від часу.

Висновки. Запропонована конструкція пристрою для очищення голівок коренеплодів від гички на кореню комбінованої дії завдяки своїм конструктивним особливостям може використовуватися в складі як бурякозбирального комбайна так і самостійною машиною та забезпечити якісні вимоги щодо чистоти коренеплодів. Раціональний режим роботи даної конструкції очисника обумовлюється коефіцієнтом кінематичного режиму роботи при дотриманні якого забезпечується очищення зрізування гички та очистка залишків черешків та зберігається цілісність тіла коренеплоду. Також, проведене дослідження створило передумови для визначення допустимих динамічних навантажень у зоні контакту лопать-корінь, для чого слід розв'язати задачу контакту про контактну взаємодію 3 урахуванням допустимих напружень у тілі кореня, виходячи з критерію його міцності і напружень руйнування залишків гички

\section{Лiтература.}

1. Посівні площі сільськогосподарських культур за їх видами.URL: http://www.ukrstat.gov.ua/

2. Козіброда Я.І. Тенденції розвитку машин для збирання цукрових буряків. - Тернопіль.: Збруч, 1996. - $91 \mathrm{c.}$

3. Ліннік А.Ю. Перспективні напрямки розвитку машин для очищення гички цукрових буряків / Ліннік А.Ю. // Формування конкурентоспроможної економіки: теоретичні, методичні та практичні засади: матеріали II міжнар. наук.-практ. конф. 21-22 березн. 2013p. - Тернопіль: Крок, 2013. - с. 83.

4. Погорілий М.Л. Технологічні і технічні аспекти вдосконалення бурякозбиральної техніки // Техніка АПК. - 2000. - № 1. - С. 14-18.

5. Хелемендик М.М. Напрями і методи розробки робочих органів сільськогосподарських машин. - К.: Аграрна наука, 2001.-280с.

6. Пат. 122643 UA A 01 D 23/02 (2006.1) Пристрій для зрізування гички та очищення головок коренеплодів цукрових буряків/ Ліннік А.Ю., Юрчишин Н.І. - №201705457 заявл. 02.06.17, опубл. 21.01.18. Бюл №2.

7. Галин Л.А. Контактные задачи теории упругости и вязкоупругости. - М.: Наука, 1980. - 304 c.

8. Кинематический анализ паралелограммного копирующего механизма. В.С. Красовских, В.А. Заварзин. Вестник Алтайского государственного аграрного университета №1 2003г..

\section{A. Linnik, I. Semeniv, O. Kyryk}

Separated Subdivision of National University of Life and Environmental Sciences of Ukraine Berezhany Agrotechnical institute

\section{CLEANER OF ROOT CROPS. CONSTRUCTIONS AND CINEMATIC MODE}

The natural potential of Ukraine's agricultural lands allows it to become a leader in sugar production in Europe. However, to successfully enter European markets, it is necessary to ensure the competitiveness of manufactured products, which can be achieved in various ways, in particular: improving the quality of raw materials, reducing labor costs and energy intensity of production processes.

The analysis of classical technologies of cleaning of heads of root crops and their collecting, influence of various constructive schemes of clearing devices on cleanliness of a head and integrity of a body of a root taking into account energy consumption on process is carried out. The problem of improvement of existing and invention of new designs of root cleaning machines taking into account physical and mechanical properties of contact bodies of a cleaner-root crop which quality of work would satisfy agrotechnical requirements is investigated. 
The article proposes a new design of a device for cutting the bud and cleaning the heads of sugar beet roots in which combines two technological processes - cutting the stem and subsequent cleaning of the root surface with a hard disk surface and elastic whips provided copying the height of each root.

The result of the study is to determine the prospects for improving the technology of cleaning sugar beet tops, proposed a new design of a combined cleaning machine.

Keywords: loops, remnants of stems, root, sugar beet, cleaning.

\section{А.Ю. Линник, И.И. Семенив, О.М. Кирик}

Обособленное подразделение Национального университета биоресурсов и природопользования Украины «Бережанский агротехнический институт»

\section{БОТВООЧИСТИТЕЛЬНОЕ УСТРОЙСТВО. КОНСТРУЦИЯ И КИНЕМАТИКАДВИЖЕНИЯ}

Природный потенциал сельскохозяйственных угодий Украины позволяет стать лидером по производству сахара в Европе. Однако, для успешного выхода на европейские рынки необходимо обеспечить конкурентоспособность выпускаемой продукции, что можно достичь разными путями, в том числе: повышение качества сырья, снижение затрат труда и энергоемкости процессов производства.

Проведен анализ классических технологий очистки головок корнеплодов и их сбора, влияние различных конструктивных схем очистных устройств на чистоту головки и целостность тела корня с учетом энергозатрат на процесс. Исследована проблема усовершенствования существующих и открытие новых конструкций гичкоочисних машин с учетом физико-механических свойств тел контакта очиститель-корнеплод, качество работы которых удовлетворила бы агротехнические требования.

В статье предложена новая конструкция устройства для срезания ботвы и очистки головок корнеплодов сахарной свеклы в которой поеднанодва технологических процесса срезание ботвы и последующее доочистки поверхности головки корнеплода жесткой поверхностью диска и эластичными бичами при копировании высоты роста каждого корнеплода.

Результатом исследования является определении перспективы совершенствования технологии очистки ботвы сахарной свеклы, предложена новая конструкция очистной машины комбинированного действия.

Ключевые слова: ботва, остатки ботвы, корнеплод, сахарную свеклу, очистка, доочистка. 